DOI: $10.15290 /$ bsl.2019.14.05

\title{
Paweł Rams
}

Ośrodek Studiów Kulturowych i Literackich nad Komunizmem

Instytut Badań Literackich PAN

e-mail: pwrams@gmail.com

ORCID: 0000-0003-3392-8107

\section{Powieści Stanisława Brzozowskiego w Polsce Ludowej. Zarys dziejów recepcji}

Pisanie o recepcji powieści Stanisława Brzozowskiego w Polsce w latach 1945-1989 należy zacząć od faktów, a więc od ich historii wydawniczej. Jest ona (niestety) dość uboga. Jako pierwsze wznowienia doczekały się Płomienie. Ukazały się w dwóch częściach: w 1946 (tom I) i 1947 (tom II) roku, nakładem Spółdzielni Wydawniczej Czytelnik, opracowane i przygotowane do druku przez Piotra Grzegorczyka. Wydanie to nie zostało opatrzone ani przedmową, ani posłowiem, ani nawet komentarzem edytorskim ${ }^{1}$. W 1950 roku wydano czeski przekład powieści z przedmową Ericha Sojki, który to przekład - ze względu na kwestie ideologiczne - nie miał w kraju dobrej prasy. W 1956 roku Wydawnictwo Literackie wznowiło Płomienie, tym razem wyposażone $\mathrm{w}$ notę edytorską, notę biograficzną, a także przypisy, wśród których znalazło się objaśnienie kontekstu przedstawionych w powieści wydarzeń ${ }^{2}$. Ostatnie przed 1989 rokiem wznowienie najpopularniejszej

1 Przypuszczalnie było to podyktowane "głodem" literatury tuż po wojnie, a więc koniecznością szybkiego dostarczania czytelnikowi książek bez możliwości ich starannego opracowania.

2 W pewnym sensie jest to coś więcej niż przedstawienie działań samej Narodnej Woli, której działacze są bohaterami powieści Brzozowskiego. Teresa Podoska - redaktorka - w posłowiu opisała dzieje ruchów rewolucyjnych w Rosji, poczynając od lat 40. XIX wieku, wskazując tym samym korzenie inicjatyw z lat 70., a także ich następstwa [zob. s. 475-488]. 
z powieści Brzozowskiego miało miejsce w 1983 roku (Warszawa, Iskry) ${ }^{3}$ z przedmową Andrzeja Mencwela.

Drugą powieścią Brzozowskiego wznowioną w okresie PRL-u był Sam wśród ludzi - pierwsza część zaplanowanej, acz niezrealizowanej nigdy dylogii pt. Dębina. Po raz pierwszy po wojnie książka ukazała się w 1957 roku w Wydawnictwie Literackim zaopatrzona w przypisy i krótką notę wydawcy, opisującą koleje powstawania dzieła oraz zawierającą objaśnienia edytorskie. Następne wydanie miało miejsce w 1979 roku w serii Biblioteki Narodowej (I 228) w opracowaniu i ze wstępem Marty Wyki. W okresie istnienia Polski Ludowej nie ukazała się żadna inna powieść z dorobku pisarza: ani skonfiskowane i pozostające w rękopisie Pod ciężarem Boga, ani wydawane w odcinkach na łamach "Głosu” Wiry, ani ostatnia, niedokończona Książka o starej kobiecie ${ }^{4}$.

Biorąc pod uwagę wyłącznie fakty związane z kolejnymi wydaniami powieści Brzozowskiego pewne zdziwienie budzi uboga oferta dzieł tego autora $\mathrm{w}$ porównaniu do zainteresowania, jakim się cieszył nie tylko w okresie międzywojennym, ale przede wszystkim od połowy lat 60. do końca kolejnej dekady. Zainteresowanie to - za sprawą przedstawicieli środowiska Warszawskiej Szkoły Historii Idei i ich uczniów - skupiało się przede wszystkim na problematyce filozoficznej, jednak również twórczość prozatorska odgrywała w tej recepcji pewną rolę. Paradoksalnie, owo zainteresowanie narodziło się przy słabej dostępności najważniejszych jego książek. Aż do lat 70. żadna z ważniejszych filozoficznych czy teoretycznoliterackich prac nie została wznowiona ${ }^{5}$. Wprawdzie w 1973 roku Wydawnictwo Literackie w porozumieniu z Państwowym Instytutem Wydawniczym powróciło do idei wydania dzieł wszystkich Brzozowskiego (pod redakcją Mieczysława Sroki, a po jego śmierci Andrzeja Mencwela), jednak w okresie PRL-u ukazały się tylko trzy tomy. Jako pierwszy - w 1973 roku - przygotowano tom Kultura i życie ze wstępem Andrzeja Walickiego. Współczesna powieść i krytyka ze wstępem Tomasza Burka została wydana 11 lat później - w 1984 roku, a trzeci tom - Wczesne prace krytyczne z przedmową Andrzeja Mencwela wyszedł w 1988 roku. Lata 80. przyniosły też reprinty Legendy Młodej Polski

\footnotetext{
3 Wydanie opiera się na wersji z 1946 roku.

4 Wszystkie one ukazały się nakładem Wydawnictwa Literackiego w serii Dzieł Brzozowskiego w 2011 i 2012 roku.

5 Na ten stan rzeczy utyskiwało wielu. Janusz Pawłowski pisze na przykład: „Całkowity brak książek krytycznych Brzozowskiego w naturalnym obiegu czytelniczym, przy równoczesnej tak żywej obecności jego idei w rozmaitych porządkach współczesności, stwarzał określone potrzeby i oczekiwania" [J. Pawłowski, Brzozowski spłycony, „Literatura" 1972, nr 15, s. 20].
} 
i Pamiętnika oraz tematyczne wybory artykułów wraz z fragmentami większych prac.

$\mathrm{Na}$ tym tle proces wydawniczy powieści nie wydaje się zaskakujący. Brzozowski istniał bardziej w dyskursie naukowym i krytycznym niż w obiegu czytelniczym. A dyskurs ów - dotyczący w tym konkretnym wypadku utworów prozatorskich - był niezwykle interesujący. Można w nim wyróżnić następujące okresy i podokresy:

1. Lata 1945-1956 to $\mathrm{z}$ jednej strony okres powojennych rozliczeń (1945-1948), z drugiej okres przemilczenia (1949-1956).

2. W latach 1956-1974 najpierw mamy do czynienia z procesem przywracania pamięci (1956-1965), po którym następuje renesans Brzozowskiego (1966-1974).

3. Lata 1974-1989 rozpoczynają dominację naukowego podejścia do autora Płomieni. Krótka charakterystyka każdego z wymienionych okresów pozwoli w zarysie przedstawić zawirowania, jakim podlegała recepcja twórczości literackiej Brzozowskiego w okresie istnienia Polski Ludowej.

\section{II}

Lata powojenne były nie tylko czasem, w którym podejmowano próby powrotu do normalności, ale także dokonywano rozliczeń z przeszłością wobec wyzwań nowej rzeczywistości, konstruowanej ze świadomością ograniczonej suwerenności. Swoisty rachunek sumienia przeprowadzała przedwojenna inteligencja, a doskonałym „wehikułem” do tego zadania okazał się właśnie Stanisław Brzozowski. To w oparciu o jego spuściznę Stanisław Adamczewski konstruował „spowiedź pokoleniową", wpisując myśl autora Idei $\mathrm{w}$ doświadczenia okresu międzywojennego oraz czasu wojny ( $\mathrm{w}$ tym również własne) ${ }^{6}$. Ocena wypadła niejednoznacznie. $Z$ jednej strony myśl Brzozowskiego nadal przyciągała, z drugiej, w obliczu gehenny wojennej, nowego odcienia nabrały jego późne teksty, w których naród i siła zyskują na znaczeniu. Adamczewski nie rozstrzygnął owego dylematu. Czytelnikowi pozostało sprawę tę przeanalizować samodzielnie. $W$ podobny sposób o myśli Brzozowskiego i jej roli w powojennej Polsce pisali Kazimierz Koźniewski oraz Janina Kulczycka-Saloni. Asumpt ku temu dało pierwsze powojenne wydanie Płomieni. O ich wpływie na lewicującą młodzież, dorastającą i kształtującą światopogląd w II RP, biorąc pod uwagę również

\footnotetext{
6 S. Adamczewski, Patronat Brzozowskiego?, „Nauka i Sztuka” 1946, nr 4.
} 
własne doświadczenia, pisał pierwszy z wymienionych autorów ${ }^{7}$. Pojawiło się u niego, podobne jak u Adamczewskiego, wahanie w ocenie spuścizny Brzozowskiego, ale także dość niejednoznaczna ocena własnego nim uwiedzenia. Autor bez ogródek wspominał, że powieść wywarła na nim wielkie wrażenie ${ }^{8}$. Tak wielkie, że nawet czternaście lat później (jak twierdzi, pierwszy raz miał z nią styczność w 1934 roku) jej wznowienie uważał za ważne wydarzenie kulturalne. Więcej nawet. Stwierdzał, że powieść ta jest tak samo czytelna jak przed wojną, a temat konspiracyjnej walki ze znienawidzoną władzą nabiera zupełnie nowego sensu po wydarzeniach drugiej wojny światowej. W słowach tych pobrzmiewają echa jego własnej działalności konspiracyjnej. Artykuł zakończony został jednak ostrzeżeniem: wydanie Płomieni nie powinno wywoływać nadmiernego optymizmu i należy ostrożnie podchodzić do pomysłu reedycji kolejnych pism Brzozowskiego. Takie postawienie sprawy spowodowało rozdarcie Koźniewskiego pomiędzy sympatią dla intelektualnego idola $\mathrm{z}$ lat młodości a partyjną wykładnią jego dzieł 9 .

$\mathrm{W}$ podobnym tonie, ale $\mathrm{w}$ zupełnie innej poetyce utrzymana była druga z recenzji Płomieni pióra Janiny Kulczyckiej-Saloni zamieszczona w „Kuźnicy" w 1948 roku $^{10}$. Swoje zainteresowanie Brzozowskim badaczka uzasadniała koniecznością rozprawienia się $\mathrm{z}$ charakteryzującą go niejednorodnością myślową. Choć autor recenzowanej powieści znany był przede wszystkim ze swoich dzieł publicystycznych i filozoficznych, to uwagi - zdaniem Kulczyckiej-Saloni - wymagał także jego dorobek literacki. Od samego początku autorka recenzji twierdziła, że pod względem artystycznym Płomienie są powieścią nieudaną. Przekonanie to argumentowała antyrealistycznością, "próżnią topograficzną", publicystycznością, jednowymiarowością postaci, brakiem zarysowania ewolucji idei narodnickiej. Autorka, w przeci-

7 K. Koźniewski, „Płomienie” Brzozowskiego, „Twórczość” 1948, z. 4, s. 109.

8 O pokoleniowym znaczeniu Płomieni inicjującym „emocjonalne związanie się z lewicą polityczną" wspomina Bronisław Baczko w tekście Absolut moralny i faktyczność istnienia. (Brzozowski w kręgu antropologii Marksa), w: Wokót myśli Stanisława Brzozowskiego, red. A. Walicki i R. Zimand, Kraków 1974, s. 127.

9 Tekst ten nabiera innego sensu, gdy zdamy sobie sprawę, iż autor był wieloletnim współpracownikiem Ministerstwa Bezpieczeństwa Publicznego. Nie przekreśla to, z mojego punktu widzenia, możliwości uznania analizowanego artykułu za tekst rozliczeniowy, jednakże każe zachować spory wobec niego dystans. Warto zastanowić się, na ile współpraca z tajnymi organami państwa wynikała $z$ doświadczenia historycznego, a na ile był to przejaw koniunkturalizmu oraz czy postawa taka wpływała na szczerość wypowiedzi krytycznych. Zob. J. Siedlecka, Kryptonim „Liryka”, Warszawa 2009.

10 J. Kulczycka-Saloni, O „Płomieniach” Stanisława Brzozowskiego. Nowa recenzja bardzo starej powieści, „Kuźnica” 1948, nr 32, s. 3. 
wieństwie do Adamczewskiego i Koźniewskiego, starała się uniknąć wpisania $\mathrm{w}$ tekst swojego emocjonalnego nastawienia do młodopolskiego filozofa. Mimo tego miała trudność nie tyle $\mathrm{z}$ dookreśleniem stanowiska zajmowanego wobec recenzowanej powieści, co z koniecznością przemyślenia własnych intelektualnych zapożyczeń. Choć Kulczycka-Saloni za wszelką cenę starała się ukryć swoje osobiste zaangażowanie w przedmiot opisu, to w recenzji pojawiły się wewnątrztekstowe znaczniki pozwalające sądzić inaczej. Badaczka bowiem bardzo dużo miejsca poświęciła przedstawieniu światopoglądu i emocji bohaterów Płomieni. Zrobiła to z niezwykłą pasją. Można odnieść wrażenie, że $\mathrm{w}$ tak zinterpretowanej powieści odnalazła samą siebie, swoją drogę do miejsca, w którym się znalazła. Recenzja nie pozostawia jednak pola do dyskusji, nie posiada otwartego zakończenia, jest tekstem zamykającym, w którym jednoznacznie uznaje się, iż Brzozowskiego zdecydowanie nie można obrać na patrona nowej epoki, a głoszone przez niego idee należy odłożyć do lamusa ${ }^{11}$.

Tekst ten współgrał z artykułem Pawła Hoffmana ${ }^{12}$ oraz książką Adama Schaffa ${ }^{13}$, czyli tekstami zamykającymi próby powojennej dyskusji nad aktualnością dziedzictwa autora Płomieni, rozpoczynającymi jednocześnie kilkuletni okres milczenia. Jedynym znanym mi odstępstwem była krótka notatka opublikowana na łamach "Głosu Ludu. [Pisma ludu pracującego na Śląsku]" na temat czeskiego przekładu powieści Brzozowskiego. Korzystając z okazji autor wzmianki o tym przekładzie przybliżył czytelnikom postać młodopolskiego pisarza i filozofa, ustosunkowując się do niego bardzo przychylnie, podkreślając przy tym jego żywy udział $w$ ruchu rewolucyjnym, a posądzenie o współpracę z carską ochraną uznając za oszczerstwo ${ }^{14}$. Informacja o przekładzie pojawiła się w tym samym roku na łamach „Nowej Kultury”. Utrzymana była jednak w oskarżycielskim tonie. Autor notki, ukrywający się pod pseudonimem pho $^{15}$, pisał:

Warto zapytać, kogo z naszego aparatu propagandy kulturalnej za granicą należy pochwalić (może odznaczyć) za zalecenie w Pradze (bądź nieprzestrzeżeniem przed wydaniem) tego paszkwilu na polski i rosyjski ruch rewolucyjny,

11 Więcej na ten temat piszę w artykule Między historia a biografia. Funkcjonowanie myśli Stanisława Brzozowskiego w latach 1945-1948, „Pamiętnik Literacki” 2017, z. 1, s. 23-48.

12 P. Hoffman, Legenda Stanistawa Brzozowskiego, „Nowe Drogi” 1947, nr 2.

13 A. Schaff, Narodziny i rozwój filozofii marksistowskiej, Warszawa 1950.

14 -eł-, Stanisław Brzozowski wśród Czechów, "Głos Ludu. Pismo ludu pracującego na Śląsku” 1950, nr 46, s. 3. Czasopismo to nie jest tożsame z "Głosem Ludu", będącym do 1948 roku organem PPR.

15 Pod pseudonimem tym krył się najprawdopodobniej Paweł Hoffman. 
jakim są Płomienie - i za popularyzowanie $\mathrm{w}$ ten sposób w zaprzyjaźnionym kraju twórczości Stanisława Brzozowskiego, prekursora polskiego faszyzmu, winowajcy straszliwego zaśmiecenia tylu głów inteligenckich ${ }^{16}$.

Polemikę z takim podejściem próbował prowadzić redaktor przywoływanego już "Głosu Ludu". Robił to nie przebierając w słowach, z równą jak jego oponent zapalczywością ${ }^{17}$. Tego typu wymiana zdań była rzadkością w okresie stalinowskim, a przymus milczenia o autorze Płomieni trwał jeszcze do 1956 roku, tak w dyskursie krytycznym i naukowym, jak w procesie wznawiania kolejnych dzieł Brzozowskiego.

\section{III}

Jeszcze zanim w Polsce Brzozowski zaczął powracać do dyskursu naukowego i krytycznoliterackiego, już w 1956 roku na łamach paryskiej „Kultury" ukazał się artykuł Michała Borwicza (właśc. Maksymilian Boruchowicz) porównujący go z André Malraux ${ }^{18}$. Jednakże za prawdziwy powrót Brzozowskiego uznać należy wznowienie Płomieni w 1956 roku, które obok wzmianek $\mathrm{w}$ prasie ${ }^{19}$ doczekało się także obszernych, pełnoprawnych recenzji. Jan Wyka ${ }^{20}$ nie tylko bardzo pozytywnie wypowiadał się o powieści, ale także polemizował z interpretacjami, jakimi obrosła postać i dzieła Brzozowskiego w okresie „kultu jednostki”. Choć autorowi wznowionej powieści wytaczał Wyka szereg zarzutów (głównie dotyczących stylu), to wydźwięk całości pozostawał pozytywny. Jednym z założeń recenzji było ukazanie Brzozowskiego jako rewizjonisty i nieszablonowego myśliciela jawnie walczącego z marksistowską ortodoksją, co jest oczywistym nawiązaniem do obowiązującej kilka lat wykładni poglądów autora Płomieni.

\footnotetext{
16 pho, Czyja to zastuga, "Nowa Kultura” 1950, nr 3, s. 8.

17 -eł-, Przeszarżowany atak "Nowej Kultury”, „Głos Ludu. Pismo ludu pracującego na Śląsku” 1950, nr 48, s. 3.

18 Polski poprzednik Malraux, „Kultura” (Paryż), 1956, nr 6, 7-8. Szkic był drukowany już przed wojną w "Sygnałach" 1937, nr 28 [https://polona.pl/item/sygnaly-sprawy-spoleczne-literaturasztuka-r-4-nr-28-1-kwietnia-1937,NTczMTg1OTY/0/\#info:metadata, dostęp 23.10.2019]. Wersja powojenna nieco różni się od tej z 1937 roku, a wprowadzone zmiany są znaczące. Największą różnicą jest dopisanie w wersji z 1956 fragmentu o podobieństwach formalnych obydwu pisarzy, a także zmiana zakończenia, w którym wzięto pod uwagę doświadczenia wojenne i związane z nimi przewartościowania.

19 A. Lam, Ksiażki przypomniane, „Nowiny Literackie i Wydawnicze” 1957, nr 2, s. 7; „Słowo Powszechne" 1957, nr 68; Literatura i polityka, "Gazeta Krakowska” 1957, nr 63.

20 J. Wyka, Płomienie, „Nowiny Literackie i Wydawnicze” 1957, nr 10/11, s. 6.
} 
Z jeszcze większym zainteresowaniem spotkało się wznowienie w 1957 roku pierwszej części nieukończonego cyklu Dębina pod tytułem Sam wśród ludzi. Stefan Lichański przypisał tej pozycji ogromne znaczenie, porównując ją nie tylko z Pałubq Irzykowskiego, ale także z Beniowskim i Królem Duchem Słowackiego, w czym można doszukać się przesady i nieumotywowanej egzaltacji ${ }^{21}$. Tę niezwykle wysoką ocenę wystawił recenzent powieści za nowatorskość oraz praktykowanie przez Brzozowskiego krytyki modelu polskości opartego na romantycznym mesjanizmie i bezrefleksyjnym kulcie szlacheckości ${ }^{22}$. Według Lichańskiego elementy te przybliżały go do innych pisarzy krytykujących mit polskości, takich jak Gombrowicz czy Witkacy ${ }^{23}$. Jednocześnie Brzozowski wyróżniał się na ich tle ze względu na swoistość prowadzonej krytyki oraz sposobu, w jaki jej dokonał. Największym i chyba jedynym zastrzeżeniem wobec Samego wśród ludzi był styl, niedociągnięcia kompozycyjne, a także miałkość niektórych fragmentów.

Ogromne znaczenie w dziejach powieści polskiej przypisywał Samemu wśród ludzi także Andrzej Kijowski, podkreślając przede wszystkim mistrzostwo w tworzeniu bohatera będącego uosobieniem wszystkiego, co w polskiej tradycji romantycznej najlepsze, ale jednocześnie najgorsze ${ }^{24}$. Nowatorskość pierwszej części planowanego cyklu przejawiała się także - zdaniem recenzenta - w podejściu autora do zagadnień psychologii kreowanych postaci. Wszystkie pozytywne wrażenia płynące z lektury były jednak niewystarczające, by móc nazwać Samego wśród ludzi arcydziełem. Są w nim bowiem „fragmenty wielkiej powieści i nie ma wielkiej powieści. Rozrasta się komentarz, nabrzmiewa problematyka filozoficzna, abstrakcja zalewa wszystko, mętnieje język, staje się ciemny, bełkotliwy, zatraca się konstrukcja, ginie bohater" 25. Kijowski, podobnie jak wielu innych krytyków, wskazywał, że powieści Brzozowskiego są wielkie pod względem zawartości ideowej, bardzo wiele brakuje im za to $\mathrm{w}$ sferze literackiej, przez co nie mogą one zyskać miana arcydzieł literatury. W podobny sposób wypowiadał się o wznowieniu recenzent "Życia i Myśli", polemizując z tezą Lichańskiego, jakoby czytelnik miał do czynienia $\mathrm{z}$ arcydziełem ${ }^{26}$. Wartość wznowionej powieści Brzozowskiego upatrywał przede wszystkim w zmuszaniu czytelnika do intelektual-

21 S. Lichański, Na miarę Fidiasza, „Orka” 1958, nr 33, s. 7. Rozszerzona wersja pod tytułem Fundamenty eposu została opublikowana w zbiorze tegoż autora Cienie i profile (Warszawa 1967).

22 S. Lichański, Na miarę Fidiasza, s. 7.

23 Tamże.

24 A. Kijowski, A byłaby tęga powieść, „Przegląd Kulturalny” 1958, nr 29, s. 5.

25 Tamże.

26 W.J.K., Samotność heroiczna, „Życie i Myśl” 1958, nr 7/8 s. 171-175. 
nego wysiłku oraz wskazywał na jej niezwykle ważną pozycję w dziejach polskiej literatury ${ }^{27}$.

Bez związku ze wspomnianymi wznowieniami dwuczęściowy szkic historycznoliteracki poświęcony twórczości prozatorskiej Brzozowskiego napisał Jan Pieszczachowicz ${ }^{28}$. Starał się zinterpretować jej przesłanie ideowe $\mathrm{w}$ szerszej perspektywie, przede wszystkim $\mathrm{w}$ kontekście pojęcia alienacji, rozumianego jako proces odrywania się części społeczeństwa polskiego od reszty narodu ${ }^{29}$. W ujęciu Pieszczachowicza powieści autora Legendy Młodej Polski nie stanowią jedynie ilustracji tez filozoficznych, ale są równoprawnym głosem na tle innych wypowiedzi tego rodzaju. Brzozowski analizując na kartach swoich utworów prozatorskich szerokie procesy społeczne, nie gubił z oczu jednostki. Więcej nawet. Kreował on swoich bohaterów w taki sposób, by przez ich pryzmat pokazać piekło nowoczesności, przez które musi przejść każdy podmiot. Stają się więc owe powieści rodzajem laboratorium doświadczalnego dla wszelkich idei, z którymi musi się zmierzyć człowiek chcący być określany mianem nowoczesnego ${ }^{30}$. W takim ujęciu twórczość literacka Brzozowskiego to zdecydowanie coś więcej niż - mniej lub bardziej - udane próby artystyczne bądź rozpisane na głosy i akcję tezy filozoficzne. To pokazanie prawdziwego trudu i walki, jakie trzeba podjąć, by na ruinach starego mógł powstać nowy człowiek. Dlatego też bohaterowie tych powieści mają najczęściej rysy heroiczne, podszyte jednak pesymizmem i samotnością ${ }^{31}$.

Prawdziwy renesans myśl Brzozowskiego przeżywała dzięki przedstawicielom Warszawskiej Szkoły Historii Idei oraz ich uczniom, próbującym w dziedzictwie autora Samego wśród ludzi odnaleźć remedium na totalitarne tendencje w marksizmie, a także lepiej zrozumieć własną drogę od stalinizmu do rewizjonizmu (przypadek Kołakowskiego i Baczki). Okres ten trwał do mniej więcej połowy lat 70., a jego zwieńczeniem była publikacja dwóch fundamentalnych monografii autorstwa Andrzeja Walickiego i Andrzeja Mencwela ${ }^{32}$. Wśród tekstów powstających w tym nurcie niewiele uwagi poświęcono twórczości literackiej. W obszarze zainteresowań bada-

\footnotetext{
27 Tamże, s. 174.

28 J. Pieszczachowicz, Płomienie i popioły, „Życie Literackie” 1967, nr 7, s. 1, 12; tenże, Płomienie i popioły (II): Głosy w ciemności, „Życie Literackie” 1967, nr 8, s. 6, 10.

29 J. Pieszczachowicz, Płomienie i popioły, s. 12.

30 J. Pieszczachowicz, Płomienie i popioły (II): Głosy w ciemności, s. 6.

31 Tamże, s. 6.

32 A. Mencwel, Stanisław Brzozowski. Kształtowanie myśli krytycznej, Warszawa 1976; A. Walicki, Stanisław Brzozowski - drogi myśli, Warszawa 1977.
} 
czy znalazła się głównie filozofia, a powieściopisarstwo stanowiło zazwyczaj wątek poboczny bądź było wprowadzane na zasadzie ilustracji poszczególnych tez. Nie można jednak zapomnieć, że twórczości literackiej doskonały szkic, o szerszych niż tylko historycznoliterackich czy recenzenckich zamiarach, poświęcił Tomasz Burek ${ }^{33}$. Autor wpisywał dokonania literackie Brzozowskiego w całość jego działalności pisarskiej, dowodząc, że w gruncie rzeczy pracował on całe życie nad jednym dziełem, a forma, jaką przyjmowały jego rozważania, przystosowana było do tego, co chciał powiedzieć, na co zwrócić szczególną uwagę. Dlatego też należy upatrywać w powieściach Brzozowskiego traktatów filozoficznych, będących próbą powiedzenia tego, czego nie można wyrazić $w$ innym niż literacki języku. Uznając wielkość tych dzieł i problematyki, jaką podejmują, Burek stawiał Brzozowskiego-powieściopisarza wśród gigantów światowej literatury modernistycznej, a więc Kafki, Manna, Brocha i Woolf. Przeszkodą w zaistnieniu w międzynarodowym obiegu okazała się przedwczesna śmierć, uniemożliwiająca pracę nad niedostatkami warsztatu artystycznego.

\section{IV}

Od połowy lat 70. miejsce recenzji i szkiców zajęły teoretyczne i historycznoliterackie rozprawy poświęcone powieściowej twórczości Brzozowskiego. Były one symptomem głębszego zjawiska, jakim stała się zmiana w podejściu do dziedzictwa autora Legendy Młodej Polski. W poprzedniej dekadzie wznowieniom książek narracyjnych Brzozowskiego towarzyszyły przede wszystkim recenzje oraz okazjonalne eseje (z rozbudowanymi niejednokrotnie analizami formalnymi), w przypadku Płomieni mocno zabarwione emocjonalnie. O takim podejściu do tych pozycji jeszcze w latach 60. wspominał Andrzej Mencwel w przedmowie do wydania tejże powieści z 1983 roku. W kolejnej dekadzie - jak zaznaczał badacz - postawa taka wyraźnie słabnie. Skłania mnie to do sformułowania tezy, iż od lat 70. spuścizna po Stanisławie Brzozowskim przestała być „tradycją żywą", a stała się „tradycją nieafektywną". Co rozumiem przez takie przeciwstawienie? Przede wszystkim zmianę kontekstu, w jakim dzieła te są czytane, ale także zmianę pokoleniową wśród samych czytających, wnoszących do lektury inne doświadczenie i inne kategorie interpretacyjne niż wcześniejsze pokolenia. Przełom lat 60. i 70. prowadzi do wygaszenia, bądź - jeżeli wolno tak powiedzieć -

33 T. Burek, Arcydzieło niedokończone, „Twórczość” 1966, nr 6. 
delegitymizacji dotychczasowego kontekstu, w którym umieszczano dorobek Brzozowskiego. Mam na myśli - upraszczając sprawę - problematykę marksistowską i idącą za nią krytykę społeczną, ale także spory o przynależność ideową autora Płomieni, które były paliwem intelektualnym jeszcze dla przedstawicieli Warszawskiej Szkoły Historii Idei. W to miejsce wkroczyły zupełnie nowe konteksty, nowe przestrzenie interpretacji. Nie chodzi tu jednak o jakieś dramatyczne zerwanie ciągłości, o porzucenie problemów pojawiających się $\mathrm{w}$ dotychczasowych badaniach nad Brzozowskim i skupienie się na nowych, dotąd nieznanych. Ewolucja, o której mowa, miała subtelny wymiar i nie znajduję $\mathrm{w}$ tym momencie dla niej lepszego określenia niż właśnie "tradycja nieafektywna”. Ta metafora ma za zadanie podkreślić zerwanie pewnej więzi, która do tej pory definiowała relacje między Brzozowskim a jego czytelnikami. Były to związki ideologiczne, intelektualne i emocjonalne, które Maciej Urbanowski nazywał tradycją „żywotną" ${ }^{44}$. Od lat 70. autor Idei tracił znaczenie jako ideolog, stawał się za to doskonałym materiałem badawczym dla historyków literatury, kultury i filozofii. „Uśmiercenie Brzozowskiego" nie oznaczało przekreślania ważności (i ważkości) jego dorobku intelektualnego dla badaczy. Zerwanie, o którym mowa, umożliwiło wpisanie Brzozowskiego w szersze tło, pozwalało dostrzec problemy, które do tej pory uchodziły uwadze badaczy, wygasić zaś emocjonalne nastawienie do jego twórczości.

Pojawienie się pełnoprawnych historycznych i teoretycznoliterackich rozpraw poświęconych powieściom Brzozowskiego było tylko jednym z przejawów dominacji "tradycji nieafektywnej” ${ }^{35}$. Wpisany w ich naturę dystans

34 „O «żywotności» danej tradycji krytycznej (krytyka) mówiłaby nam tak czy owak jej recepcja, liczona także głosami sprzeciwu. Ważne zapewne są tutaj przywołania nazwiska danego krytyka, składane mu wyrazy uznania, ale też gesty nawiązywania do jego myśli, które mogą mieć charakter epigońskiej, bezmyślnej repetycji, ale też kontynuacji, a nawet refutacji. Tradycja 'żywotna' kształtuje nasze sposoby czytania literatury, w tym nasz język krytyczny, w tym i takie „drobiazgi", jak tytuły recenzji czy esejów albo decyzje o wyborze samych gatunków krytycznych. Zresztą ze względu na liczbę cytowań Brzozowski z pewnością był zresztą jedną z najbardziej 'żywych' tradycji powojennej krytyki [...]. Z całą pewnością Brzozowski współdecydował też o karierze wielu powojennych gatunków krytycznych: polskiego eseju, w tym zwłaszcza portretu, a dalej pamfletu oraz dziennika lektur" [M. Urbanowski, Brzozowski i powojenna krytyka literacka, w: tegoż, Od Brzozowskiego do Herberta..., s. 52]. Ujęcie to nie jest tożsame z moim rozumieniem, ale można je potraktować jako komplementarne. Podobnie o kwestii tej wypowiada się Michał Sprusiński [„Dziennik myśli" Stanisława Brzozowskiego, „Twórczość” 1970, nr 11, s. 99].

35 Jak każde tego rodzaju uogólnienie, także w tym wypadku musimy potraktować je jako mocno umowne. Przykładem, który burzy tę opozycję jest działalność krytycznoliteracka Tomasza Burka. Chociaż zajmuje się on powieściami Brzozowskiego, publikuje swoje teksty głównie po 1968 r., to Brzozowski jest dla niego zdecydowanie tradycją „,żywotną" w rozumieniu, jakie 
pozwalał badaczom w zupełnie nowy sposób spojrzeć na całość dorobku narracyjnego Brzozowskiego. Do tej pory to Płomienie były najbardziej znaną jego powieścią, choć, jak twierdziło wielu badaczy, wcale nie najlepszą pod względem artystycznym. Hierarchia ta utrzymywała się przez wzgląd na zawartość ideową książki, wzbudzającą "duchowe poruszenie" wśród kolejnych pokoleń odbiorców. Wygaszenie emocjonalnej więzi między treścią powieści Brzozowskiego a czytelnikiem pozwalało spojrzeć na całość jego twórczości w zupełnie nowy sposób, budując nowe relacje i nowe hierarchie. Doskonałym tego przykładem jest książka Marty Wyki Brzozowski i jego powieści ${ }^{36}$.

Wyjątkowość zaproponowanego ujęcia polegała na opisaniu powieści Brzozowskiego $\mathrm{w}$ kategoriach historii literatury. Zazwyczaj opis taki nie jest niczym zaskakującym, traktuje się go jako coś naturalnego, oczywistego w odniesieniu do badań epok dawno zamkniętych. W tym konkretnym przypadku ma on jednak swoją wagę i znaczenie, wynikającą z dotychczasowego sposobu recepcji, dalekiego od niezaangażowanego, zdystansowanego spojrzenia. Wyka wpisywała się swoją książką w "tradycję nieafektywną", co umożliwiało jej właśnie takie podejście. Opisywała wszystkie powieści Brzozowskiego, łącznie ze skonfiskowanym rękopisem Pod ciężarem Boga, umieszczając je w szerokiej perspektywie historycznej, ale nade wszystko - i to jest dla mnie najważniejsze - pośród prądów intelektualnych i literackich epoki ${ }^{37}$. To z kolei dawało szansę na bardziej „obiektywną” ocenę twórczości fabularnej autora Głosów wśród nocy. Autorka trafnie rozpoznała pole dotychczasowych interpretacji, pisząc:

Fabularna twórczość Brzozowskiego poddawana była na ogół przez krytykę zabiegom porównawczym: zestawiano mianowicie fabuły z dyskursem filozoficznym, fikcję powieściową z rzeczywistością myślową autora Idei. Postępowanie

nadaje jej Maciej Urbanowski [zob. poprzedni przypis]. Twórczość Burka łączy wiele elementów, które, w zaproponowanej przeze mnie klasyfikacji, przypisane zostały do przeciwstawnych grup.

36 M. Wyka, Brzozowski i jego powieści, Kraków 1981 (dalej w tekście jako BP z podaniem numeru strony). Wyka publikowała wcześniej prace na temat powieści Brzozowskiego [W kręgu "Płomieni”, „Miesięcznik Literacki” 1972, nr 11, s. 48-58; Pierwsze powieści Brzozowskiego, „Ruch Literacki” 1973, z. 5, s. 291-300; "Sam wśród ludzi” Brzozowskiego. Propozycje interpretacyjne, „Pamiętnik Literacki" 1972, z. 2, s. 3-17; Bohater w powieściach Brzozowskiego, w: Wokót myśli..., s. 311-329; Brzozowskiego powieść nienapisana, „Ruch Literacki” 1979, z. 3, s. 157-168]. Poprzedziła również obszernym wstępem wydanie Samego wśród ludzi w serii Biblioteki Narodowej, jednak to książka stanowi najpełniejsze opracowanie i do niej będę się odwoływał w dalszej części.

37 Ten sam element podkreśla Bogdan Rogatko w recenzji książki Wyki [B. Rogatko, Od Przybyszewskiego do Kafki, czyli Brzozowskiego powieści o pracy, „Życie Literackie” 1981, nr 40, s. 15, 17]. 
takie prowadziło do konkluzji, iż Brzozowski pisał jedno wielkie Dzieło, nie znające granic gatunkowych, zaś żywiące się przede wszystkim sokami filozoficznej gleby. Sądom tym nie można odmówić racji [BP, s. 9].

Uznając zatem odczytanie takie za zasadne, próbowała wprowadzić własny punkt widzenia, stwierdzając:

Ale w momencie, gdy Brzozowski zaczyna tworzyć w sobie świadomość powieściopisarza, gdy respektuje odmienne, indywidualne prawa, jakimi rządzi się świat powieści, nici łączące jego myślenie filozoficzne $\mathrm{z}$ "fabularnym" stają się trudniejsze do wyśledzenia. Brzozowski dla każdego rodzaju swojej pisarskiej aktywności budował teoretyczne uzasadnienie. Bez nich nie potrafił po prostu odpowiedzialnie funkcjonować. Podobnie postępował więc, gdy powieść stała się przedmiotem jego praktycznego zainteresowania [BP, s. 9].

Gest oddzielenia powieści od reszty działalności pisarskiej Brzozowskiego był zabiegiem nadającym tym pierwszym znaczenie, wyjątkowość, a co za tym idzie, czynił z nich osobny przedmiot refleksji z charakterystyczną dla niego metodologią ${ }^{38}$. Wyka nie rezygnowała $\mathrm{z}$ filozoficznego namysłu nad treścią powieści, nadała mu jednakże odmienny sens: nierozerwalnie splotła go z rozważaniami na temat formy narracyjnej. Nie ma $\mathrm{w}$ tym wypadku mowy o podporządkowaniu jednego aspektu drugiemu. Badaczka traktowała je jako nierozdzielne, wykazując tym samym, że wybór określonego typu narracji miał dla Brzozowskiego bardzo silne motywacje teoretyczne, a jednocześnie uzupełniał dyskurs filozoficzny. Pod ciężarem Boga oraz Wiry to nie tylko wyraz niewyrobienia pisarskiego, ale przede wszystkim próba twórczej dyskusji z mistrzem młodości - Przybyszewskim, tak na gruncie założeń światopoglądowych, jak i w warstwie strukturalnej. Wybór określonej narracji miał więc swoje głębokie umocowanie, był także świadectwem uwikłania Brzozowskiego $\mathrm{w}$ prądy literackie epoki (i w zmagania z nimi):

Monologi wewnętrzne Czyńskiego, bohatera Pod ciężarem Boga, zbudowane bardzo podobnie jak „kolisko monologów rozpaczy” z Próchna (tak je nazwał Brzozowski), są najważniejszym źródłem wiedzy psychologicznej o tej postaci. Intymne wyznanie, tak charakterystyczne dla większości bohaterów modernistycznej prozy, pełni istotną funkcję światopoglądową, i najprawdopodobniej autor akceptuje ten właśnie typ wypowiedzi. Styl przypisany Czyńskiemu nie jest więc maską ani konwencją, nie jest również pastiszem, lecz kalką obowiązujących w epoce rodzajów narracji [BP, s. 193].

38 Problematyka ujęcia powieści jako oddzielnych od reszty dyskursu Brzozowskiego jest szczególnie wyeksponowana w recenzji książki Wyki autorstwa Małgorzaty Szpakowskiej [M. Szpakowska, Powieść jako powieść, „Twórczość” 1982, nr 1]. 
W ten sam sposób zanalizowane zostały pozostałe powieści Brzozowskiego: Płomienie, Sam wśród ludzi, Ksiażka o starej kobiecie. Użycie różnorodnych modeli konstrukcji narracji (poetyka dokumentu w Płonieniach, model powieści rozwojowej w Samym wśród ludzi, poetyka punktów widzenia w Ksiażce o starej kobiecie) miało bardzo konkretną motywację gatunkową, ale i filozoficzną. Brzozowski za każdym razem testował, która z dostępnych form w najlepszy sposób odpowiadać będzie danej treści i fazie rozwoju, w której powstawała. Pogląd taki kłóci się z fałszywym, ale jednak ciągle żywym wówczas przekonaniem o niewielkiej wadze, jaką autor przywiązywał do formy swoich wypowiedzi, ale także $z$ opinią o jego niewrażliwości na problemy estetyczne sztuki w ogóle.

Książka Marty Wyki zawiera bardzo dużo interesujących propozycji interpretacyjnych, o których nie będę tu pisał. Chciałbym jednak podkreślić, na czym - w moim przekonaniu - opiera się niezwykłość analizowanej pozycji. Wyka jako pierwsza uznała powieści Brzozowskiego za pełnowartościowe dzieła literackie, w związku z tym przeprowadziła gruntowne badanie genologiczne $\mathrm{z}$ uwzględnieniem wpływów, tradycji różnych gatunków i polemik z nimi, a także przeanalizowała związki formy z problemami natury światopoglądowej. Autorka w swoich rozważaniach - idąc w ślady Brzozowskiego - potraktowała te dwa elementy jako nierozłączne, wzajemnie na siebie wpływające i warunkujące ${ }^{39}$. Oprócz zastosowania tej zasady w praktyce czytelnik znajdzie $w$ jej książce najciekawsze (i chyba do tej pory najpełniejsze i najbardziej klarowne) omówienie poglądów Brzozowskiego dotyczących teorii powieści, będących jednocześnie dowodem na jego wyjątkowość w polskiej kulturze. Za sprawą Wyki otrzymujemy nie tylko niezwykły portret powieści Brzozowskiego, ich autora, ale także epoki i prądów na nie oddziałujących. To najlepsze w okresie PRL-u i do dziś klasyczne studium mogło jednak powstać tylko dzięki zerwaniu emocjonalnych więzi i wpisaniu tak Brzozowskiego, jak i jego dzieł w przestrzeń historycznoliteracką. Paradoksalnie uśmiercenie ideologicznej warstwy tekstów umożliwia narodziny Brzozowskiego dla badań historycznoliterackich.

Książka Wyki nie była jedyną pozycją o twórczości narracyjnej autora Idei opublikowaną w latach 70. Kilka lat wcześniej ukazało się bowiem interesujące studium Jerzego Z. Maciejewskiego zatytułowane $W$ kłębowisku prze-

\footnotetext{
39 Rys ten widoczny jest także w działalności Marty Wyki wykraczającej poza rok 1989. Zob. interesujące rozważania dotyczące roli komentarza poetyckiego w dziełach Brzozowskiego zamieszczone w tekście „Poznawać dusze twórcze...", w: S. Brzozowski, Komentarze poetyckie, wybór i wstęp M. Wyka, oprac. tekstu M. Urbanowski, Kraków 2001.
} 
ciwieństw. Obraz idei w prozie narracyjnej Stanisława Brzozowskiego ${ }^{40}$. Jego autor - co sugeruje już zresztą sam tytuł - pozostawał pod wyraźnym wpływem filozoficznych badań nad spuścizną autora Głosów wśród nocy. Choć w Słowie wstępnym pada wyraźna deklaracja o zainteresowaniu zarówno sferą ideową, jak i formalną analizowanego materiału ${ }^{41}$, to jednak ten pierwszy komponent zdecydowanie przeważa nad drugim. Lektura książki Maciejewskiego zaświadcza, że znajdował się on pod przemożnym wpływem jeszcze żywej w tym czasie fascynacji odkrytym na nowo Brzozowskim-filozofem. Powieści - pomimo prób ich separacji od reszty prac - zlewają się z nimi w jedno wielkie Dzieło, o płynnych, nie do końca jasnych granicach gatunkowych i artystycznych. I tu znów konieczne zastrzeżenie: nie można rozpoznania tego traktować jako zarzutu pod adresem autora, lecz jako wskaźnik pewnej szerszej tendencji, pewnego nurtu interpretacyjnego, w który się wpisuje swoją publikacją. Książka skupia się wyłącznie na materiale powieściowym, w nim zaś - na warstwie ideowej, uwzględniając liczne konteksty filozoficzne, światopoglądowe oraz uwikłanie w wielkie dyskusje nad nowoczesnością, prowadzone $\mathrm{w}$ okresie powstawania poszczególnych utworów. Maciejewski analizował oczywiście zabiegi konstrukcyjne i artystyczne stosowane przez Brzozowskiego. W całości dowodzenia pełnią one jednak rolę drugorzędną. Mają charakter luźnych uwag (w większości trafnych), czasami przeradzają się $\mathrm{w}$ dłuższe analizy, nie zostaje jednak sproblematyzowany ich związek z przekazem ideowym powieści, a więc nie zyskują pełnego, formalnego uzasadnienia. Praca Maciejewskiego pozostaje pod dużym wpływem sposobu pisania o Brzozowskim z lat 60 . Wprawdzie autor próbował poddać pod rozwagę formalne aspekty jego prozy, to nadal pełniły one rolę służebną wobec naczelnej, filozoficznej linii interpretacyjnej. Powieści nie stają się zatem samoistnym, wydzielonym $\mathrm{z}$ reszty pisarstwa obszarem podlegającym pełnej, teoretyczno- i historycznoliterackiej analizie. Nie zyskują autonomii, pozostając elementem wielkiego dzieła Brzozowskiego.

Podobną tendencję można zaobserwować także u Marka Grygorowicza, autora dwóch prac poświęconych Brzozowskiemu - powieściopisarzowi wydanych w $1972^{42}$ i $1973^{43}$ roku. Powieści potraktowane zostały tam jako część

40 J.Z. Maciejewski, W kłębowisku przeciwieństw. Obraz idei w prozie narracyjnej Stanisława Brzozowskiego, Warszawa-Poznań 1974.

41 Tamże, s. 5.

42 M. Grygorowicz, Samotność i wspólnota. Antynomie myśli w „Płomieniach” Stanisława Brzozowskiego, "Zeszyty Naukowe Uniwersytetu Łódzkiego. Nauki Humanistyczno-Społeczne” 1972, seria I, z. 90, s. 29-47.

43 M. Grygorowicz, Rola krytyki w kształtowaniu koncepcji powieściopisarstwa SB, „Litteraria” 1973, t. 5, s. 97-136. 
większej całości, bez uwzględniania problemów gatunkowych, za to z licznymi nawiązaniami do ogólnych tendencji i nurtów myśli Brzozowskiego, całego jego światopoglądu. Zderzenie dyskursu krytycznoliterackiego i powieściowego autora Głosów wśród nocy w tekście Grygorowicza z 1973 było raczej próbą zarysowania teorii powieści Brzozowskiego, niż badaniem swoistości formy tworzonych przez niego narracji. Artykuł z 1972 roku, bezpośrednio traktujący o Płomieniach, zawiera wprawdzie obszerny fragment dotyczący formy powieści, nie zostają jednak z tego faktu wyciągnięte wnioski o wzajemnym warunkowaniu poetyki i treści ideowych. Tu również, podobnie jak w przypadku Maciejewskiego, możemy śmiało mówić o fascynacji Brzozowskim - filozofem, który część swoich rozważań postanowił wyrazić w formie narracyjnej, podporządkowanej naczelnej zasadzie „krystalizacji idei”.

Na zasadzie przypisu warto wspomnieć, że narracyjna twórczość autora Idei nie ogranicza się wyłącznie do prac poświęconych mu bezpośrednio. Jego powieści są przedmiotem analizy w wielu książkach, nie tylko historycznoliterackich, ale również tych z zakresu teorii. Nie mam możliwości odwołania do nich wszystkich (jest to zbiór przekraczający wyznaczone ramy artykułu) ${ }^{44}$, chciałbym jednak wspomnieć o pracy Powieść młodopolska Michała Głowińskiego, wydanej po raz pierwszy w $1969^{45}$. Brzozowski zajmuje w niej marginalne miejsce (co nie znaczy, że autor nie przypisuje mu wagi). Otóż Głowiński postawił sobie za cel strukturalną analizę przemiany gatunku powieściowego w okresie Młodej Polski. Rozważania skoncentrowane zostały na elementach formalnych, badacz podjął próbę opisania w kategoriach poetyki historycznej krystalizacji gatunku na przełomie XIX i XX wieku w kontekście wcześniej ukształtowanych poetyk. Autor tego niezwykle cennego opracowania najwięcej uwagi poświęcił nie Płomieniom czy Samemu wśród lu$d z i$, ale nieukończonej Książce o starej kobiecie, mającej - ze względu na przyjętą perspektywę - dużo większe znaczenie niż uprzednio wymienione pozycje. Pomimo tej ważnej dla zrozumienia dziejów gatunku na przełomie wieków pracy, pomimo próby zespolenia formalnego i ideowego czytania powieści, zaproponowanego przez Martę Wykę, autor Płomieni dla większości interpretatorów pozostawał przede wszystkim filozofem wyrażającym swoje poglądy w różnych gatunkach i rodzajach literackich.

44 Np. w książce Zbigniewa Jarosińskiego Literatura i nowe społeczeństwo. Idee lewicy literackiej Dwudziestolecia Międzywojennego (Warszawa 1983) Brzozowski pojawia się jako tło. Podobnie zresztą w pracy Mariana Stępnia Polska lewica literacka (Warszawa 1985), w której Brzozowski powinien zajmować zdecydowanie więcej miejsca.

45 Posługuję się wydaniem drugim opublikowanym w ramach Prac wybranych, t. 1, Kraków 1997. 


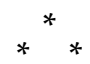

Podsumowując, powieści Brzozowskiego, pomimo nieustannego kształtowania przez nie świadomości inteligencji po 1945 roku, nie doczekały się proporcjonalnego $\mathrm{w}$ stosunku do tego wpływu zainteresowania wydawniczego. Bardzo trudno określić przyczynę takiego stanu rzeczy. Odgrywały one jednak ważną rolę $\mathrm{w}$ dyskursie naukowym poświęconym ich twórcy, chociaż poboczną w stosunku do problematyki filozoficznej. Paradoksalnie największym zainteresowaniem powieści Brzozowskiego cieszyły się tuż po wojnie oraz w ostatnich piętnastu latach Polski Ludowej. W pierwszym wypadku zadecydowało o tym pokoleniowe czytanie Płomieni, próba przeniesienia ideałów młodości w powojenną rzeczywistość. $W$ drugim - niebagatelną rolę odegrało zerwanie emocjonalnej więzi z postacią i dorobkiem Brzozowskiego, co pozwoliło uczynić z jego dzieł literackich pełnoprawny przedmiot badań historycznoliterackich. Nie można też pominąć faktu, iż w całej twórczości Brzozowskiego powieści zajmują miejsce mniej eksponowane, nie są też tak nowatorskie, jak jego rozważania teoretyczne i krytycznoliterackie. Bez wzięcia pod uwagę tego czynnika przedstawiona przeze mnie recepcja powieści Brzozowskiego w Polsce Ludowej byłaby w jakimś stopniu niepełna.

\section{Bibliografia}

-eł- (1950), Przeszarżowany atak „Nowej Kultury”, „Głos Ludu. Pismo ludu pracującego na Śląsku", nr 48, s. 3.

-eł- (1950), Stanistaw Brzozowski wśród Czechów, „Głos Ludu. Pismo ludu pracującego na Śląsku", nr 46, s. 3.

Adamczewski Stanisław (1946), Patronat Brzozowskiego?, „Nauka i Sztuka”, nr 4, s. $31-45$.

Baczko Bronisław (1974), Absolut moralny i faktyczność istnienia. (Brzozowski w kręgu antropologii Marksa), w: Wokół myśli Stanisława Brzozowskiego, red. A. Walicki, R. Zimand, Kraków: Wydawnictwo Literackie, s. 127-178.

Borwicz Michał (1956), Polski poprzednik Malraux, „Kultura” (Paryż), nr 6, 7-8, s. 27-34; 39-56.

Brzozowski Stanisław (1946), Płomienie. Z papierów po Michale Kaniowskim, Kraków: Spółdzielnia Wydawnicza Czytelnik.

Brzozowski Stanisław (1956), Płomienie. Z papierów po Michale Kaniowskim, teksty i przypisy oprac. T. Podoska, Kraków: Wydawnictwo Literackie.

Brzozowski Stanisław (1957), Sam wśród ludzi, Kraków: Wydawnictwo Literackie.

Brzozowski Stanisław (1979), Sam wśród ludzi, oprac. M. Wyka, Wrocław: Zakład Narodowy im. Ossolińskich. 
Brzozowski Stanisław (1983), Płomienie. Z papierów po Michale Kaniowskim, słowo wstępne A. Mencwel, Warszawa: Iskry.

Brzozowski Stanisław (2012), Pod ciężarem Boga. Wiry. Płomienie, posł. M. Wyka, Kraków: Wydawnictwo Literackie.

Burek Tomasz (1966), Arcydzieło niedokończone, „Twórczość”, nr 6, s. 73-96.

Głowiński Michał (1997), Powieść młodopolska, Kraków: Universitas.

Grygorowicz Marek (1972), Samotność i wspólnota. Antynomie myśli w "Płomieniach" Stanisława Brzozowskiego, "Zeszyty Naukowe Uniwersytetu Łódzkiego. Nauki Humanistyczno-Społeczne", seria I, z. 90, s. 29-47.

Grygorowicz Marek (1973), Rola krytyki w kształtowaniu koncepcji powieściopisarstwa Stanisława Brzozowskiego, „Litteraria”, t. 5, s. 97-136.

Hoffman Paweł (1947), Legenda Stanisława Brzozowskiego, „Nowe Drogi”, nr 2, s. 103-135 .

Jarosiński Zbigniew (1983), Literatura i nowe społeczeństwo. Idee lewicy literackiej Dwudziestolecia Międzywojennego, Warszawa: Czytelnik.

Kijowski Andrzej (1958), A byłaby tęga powieść, „Przegląd Kulturalny”, nr 29, s. 5.

Koźniewski Kazimierz (1948), „Płomienie” Brzozowskiego, „Twórczość”, z. 4, s. 109-112.

Kulczycka-Saloni Janina (1948), O „Płomieniach” Stanisława Brzozowskiego. Nowa recenzja bardzo starej powieści, „Kuźnica”, nr 32, s. 3-4.

Lam Andrzej (1957), Książki przypomniane, „Nowiny Literackie i Wydawnicze”, nr 2, s. 7.

Lichański Stefan (1958), Na miarę Fidiasza, „Orka”, nr 33, s. 7.

Lichański Stefan (1967), Fundamenty eposu, w: S. Lichański, Cienie i profile, Warszawa: PIW.

Maciejewski Jerzy Z. (1974), W kłębowisku przeciwieństw. Obraz idei w prozie narracyjnej Stanisława Brzozowskiego, Warszawa-Poznań: Towarzystwo Naukowe w Toruniu.

Mencwel Andrzej (1976), Stanisław Brzozowski. Kształtowanie myśli krytycznej, Warszawa: Spółdzielnia Wydawnicza Czytelnik.

Pawłowski Janusz (1972), Brzozowski spłycony, „Literatura”, nr 15, s. 20.

pho (1950), Czyja to zastuga, "Nowa Kultura”, nr 3, s. 8.

Pieszczachowicz Jan (1967), Płomienie i popioły, „Życie Literackie”, nr 7, s. 1, 12.

Pieszczachowicz Jan (1967), Płomienie i popioły (II): Głosy w ciemności, „Życie Literackie", nr 8, s. 6, 10.

Rams Paweł (2017), Między historia a biografia. Funkcjonowanie myśli Stanisława Brzozowskiego w latach 1945-1948, „Pamiętnik Literacki”, z. 1, s. 23-48.

Rogatko Bogdan (1981), Od Przybyszewskiego do Kafki, czyli Brzozowskiego powieści o pracy, "Życie Literackie”, nr 40, s. 15, 17.

Schaff Adam (1950), Narodziny i rozwój filozofii marksistowskiej, Warszawa: Książka i Wiedza.

Sprusiński Michał (1970), „Dziennik myśli” Stanisława Brzozowskiego, „Twórczość”, nr 11, s. 99.

Stępień Marian (1985), Polska lewica literacka, Warszawa: PWN.

Szpakowska Małgorzata (1982), Powieść jako powieść, „Twórczość”, nr 1, s. 121-123.

Urbanowski Maciej (2013), Brzozowski i powojenna krytyka, w: M. Urbanowski, Od Brzozowskiego do Herberta, Łomianki: Wydawnictwo LTW, s. 51-69. 
W.J.K. (1958), Samotność heroiczna, „Życie i Myśl”, nr 7/8, s. 171-175.

Walicki Andrzej (1977), Stanisław Brzozowski - drogi myśli, Warszawa: PWN.

Wyka Jan (1957), Płomienie, „Nowiny Literackie i Wydawnicze”, nr 10/11, s. 6.

Wyka Marta (1972), „Sam wśród ludzi” Brzozowskiego. Propozycje interpretacyjne, „Pamiętnik Literacki", z. 2, s. 3-17.

Wyka Marta (1972), W kręgu „Płomieni”, „Miesięcznik Literacki”, nr 11, s. 48-58.

Wyka Marta (1973), Pierwsze powieści Brzozowskiego, „Ruch Literacki”, z. 5, s. 291-300.

Wyka Marta (1974), Bohater w powieściach Brzozowskiego, w: Wokót myśli Stanisława Brzozowskiego, red. A. Walicki, R. Zimand, Kraków: Wydawnictwo Literackie, s. 311-329.

Wyka Marta (1979), Brzozowskiego powieść nienapisana, „Ruch Literacki”, z. 3, s. 157-168 .

Wyka Marta (1981), Brzozowski i jego powieści, Kraków: Wydawnictwo Literackie.

Wyka Marta (2001), „Poznawać dusze twórcze...", w: S. Brzozowski, Komentarze poetyckie, wybór i wstęp M. Wyka, oprac. tekstu M. Urbanowski, Kraków: Wydawnictwo Literackie, s. 5-30.

\title{
Stanisław Brzozowski's Novel in the Polish People's Republic: The Outline of Reception History
}

\begin{abstract}
This paper is an analysis of the discourse emerging around the novels by Stanisław Brzozowski in Poland between 1945 and 1989. The publishing timeline sets the background for the more important focus on the reception of his work. Three distinct periods are discussed - 1945-1956, when his novels were regarded as an aftermath of the interwar period, and thus banned under the Stalinist regime; 1956-1974, when his work was frequently reprinted and became a subject of historical and literary research; finally, 1974-1989, when Brzozowski's novels came under proper academic scrutiny.
\end{abstract}

Keywords: Polish novel, reception, literary criticism, cultural policy, Polish People's Republic 